\begin{tabular}{|l|l|l||}
\hline \multicolumn{2}{|c|}{ PublisherInfo } \\
\hline \hline PublisherName & $:$ & BioMed Central \\
\hline \hline PublisherLocation & $:$ & London \\
\hline \hline PublisherImprintName & $:$ & BioMed Central \\
\hline \hline
\end{tabular}

\title{
Prohibitin SNP as breast cancer indicator
}

\begin{tabular}{||l|l|l||}
\hline \multicolumn{2}{|c||}{ ArticleInfo } \\
\hline \hline ArticleID & $:$ & 4091 \\
\hline \hline ArticleDOI & $:$ & $10.1186 /$ gb-spotlight-20010522-01 \\
\hline \hline ArticleCitationID & $:$ & spotlight-20010522-01 \\
\hline \hline ArticleSequenceNumber & $:$ & 162 \\
\hline \hline ArticleCategory & $:$ & Research news \\
\hline \hline ArticleFirstPage & $:$ & 1 \\
\hline \hline ArticleLastPage & $:$ & 2 \\
\hline \hline & & RegistrationDate : 2001-05-22 \\
ArticleHistory & $:$ & OnlineDate $:$ 2001-05-22 \\
\hline \hline ArticleCopyright & $:$ & BioMed Central Ltd2001 \\
\hline \hline ArticleGrants & $:$ & \\
\hline \hline ArticleContext & $:$ & 130592211 \\
\hline \hline
\end{tabular}




\section{Tudor Toma}

Email: ttoma@mail.dntis.ro

The 3' untranslated region of the prohibitin gene encodes an RNA molecule that arrests cell proliferation when injected into breast cancer cell lines. A single base change in this region creates a variant $\mathrm{T}$ allele that lacks the antiproliferative activity of the more common functional $\mathrm{C}$ allele. In the May 19 Lancet, Eldon Jupe and colleagues from Oklahoma Medical Research Foundation, Oklahoma City, present evidence that women carrying the prohibitin $\mathrm{T}$ allele have increased susceptibility to breast cancer.

Jupe et al. performed a case-control study of prohibitin genotype in women who had been diagnosed with breast cancer within the past 18 months and healthy female controls. They found a significant association between the $\mathrm{T}$ allele and breast cancer in women who reported a first-degree relative with the disease $(2.5, p=0.005)$. A stronger association was found in a subset of women diagnosed at or before 50 years of age $(4.8, p=0.003)$.

Because the prohibitin $\mathrm{T}$ allele is common and the assay is simple and inexpensive to do, prohibitin genotyping has the potential to become an effective screening tool for determining breast cancer risk in women with first degree relatives with the disease.

\section{References}

1. Jupe ER, Badgett AA, Neas BR, Craft MA, Mitchell DS, Resta R, Mulvihill JJ, Aston CE, Thompson LF: Single nucleotide polymorphism in prohibitin 3' untranslated region and breast-cancer susceptibility. Lancet 2001, 357:1588-1589, [http://www.thelancet.com]

2. Oklahoma Medical Research Foundation, [http://www.omrf.ouhsc.edu/]

This PDF file was created after publication. 